\title{
126 Days of \\ Continuous Sunshine
}

\section{Gerald Jay Goldberg}

Hugh Bundy did not care for violence but he was ready should it come banging on his doorbell. This Hugh Bundy was no coward. He was a bus driver. Welcome aboard!

After fifty-two uneventful but edgy years in Los Angeles, Hugh discovered that he had a lump on his backside. It came as a surprise. He had expected Franky and Bone, two teenagers driving wildly through Beverly Hills south of Sunset with high-powered air rifles shooting out the rear windows of thirty-seven parked cars. Though he lived nowhere near Beverly Hills, Hugh detected a lump. It felt as if it covered one entire buttock. It felt as if it covered both buttocks and the back of his right thigh down to the calf.

Through the open bathroom window the vaguely sinister smell of nightblooming jasmine filled the air as he lowered his trousers. Their worn seat shimmered like a sea stone. Hugh looked expectantly into the medicine chest mirror while holding his wife's compact down and somewhat off to the right. Into the round mirror of the compact came an eerie, undulating, heart-stopping simulacrum of the family toilet brush. Hugh adjusted the focus. His backside loomed into view, bleak as Alaska, white as death. Leaning closer to the medicine chest, he picked out of the compact's reflected image a small area of slight discoloration that appeared to be no larger than an elevator button. In time it might grow to be as big as a trombone case.

"This is no more than a pimple," he said aloud. "Tomorrow it will come to a head and that will be that."

Setting the compact down, he gingerly tapped the sore spot. It felt mushy. It felt like a hard little ball. It felt terrible.

"Ridiculous," said Hugh, lifting his pants and pulling his tie through his belt buckle. From his unzipped fly his forgotten shirttail hung out exposing his Chinese laundry number. His number was HB 33.

The next morning the telephone rang awakening him at 6:17. It was a burglar casing the house who hung up as soon as Hugh picked up the receiver. It was 
an obscene call thick with perspiration and heavy breathing. It was his daughter who worked as a profiling machine operator for Lockheed and lived with a lousy bunch of swinging singles in Burbank where she was hysterical after attending a party the night before at which she had eaten gobs of potato salad that, according to the police report, had been adulterated with an undetermined hallucinogenic drug. It was a wrong number. It was his boss, Wismer, saying that one of the drivers had called in sick, and asking him to report for duty even though it was Saturday.

"Who was it, Hugh?" asked Mrs. Bundy when he returned to the bedroom.

Hugh sat down heavily on the edge of the bed. "Guess," he said in disgust.

There was no pain. BY GOD, THERE WAS NO PAIN! Hugh's fingers groped over his rear end, poking for confirmation. The lump had gone as mysteriously as it had come, stealing away under cover of darkness, zinc oxide, calamine lotion, and baking soda. This time he had been lucky, he thought as he polished off his Corn Flakes, but what of the next? Los Angeles had changed in fifty-two years. Things just weren't the same anymore. A different class of people with cool eyes had moved in from the South to ravage and collect welfare. Could his aging system meet the challenge? From his handkerchief drawer, Hugh removed his .22 caliber revolver and, after checking to make certain that it was loaded, stuffed it into his waistband.

"Not on Saturday, Hugh," pleaded Mrs. Bundy. "You're not going to work on Saturday, too? I'll be all alone here."

"You know where yours is," he said. "If you need extra ammunition, it's under the hankies. I've got to go."

SIG-ALERTS. They filled Hugh's head as he drove to work, zigzagging off one freeway and onto another. High winds on the San Bernardino: campers and trailers forbidden. Elsewhere a mattress burning on the Harbor. A ten-car chain reaction WITH INJURY on the Ventura. Cattle loose on the Santa Monica. A refrigerator on the Golden State. Delays amounting to as much as three weeks. The California Highway Patrol strongly advises motorists to use alternate routes until further notice. And that's the picture from high atop everything in Whirlybird \#1. Ciao, bubbela!

Pico was bumper to bumper. All of Los Angeles moving out to the desert via the surface streets and it wasn't even $7: 15$. The first tremor was felt at exactly 7:02 and located in the Inglewood area. Seismologists at Cal Tech state that it measured .7 on the Richter scale. As yet there is no accurate estimate of the property damage or loss of life but initial eyewitness reports indicate great gaping holes.

Hugh glanced anxiously through the windows of the nearby cars for a sign of fear and trembling but saw only lunch pails and peeve. A sonic boom, perhaps?

On the corner of Figueroa stood blind George. Rain or shine, like the postman or iodized salt. Odd the way there had been hardly any precipitation to speak of that year. Unnatural you might say. People were restless, fire insurance unobtainable in the canyons. Nobody ever mentioned it when they boarded his bus, but Hugh know is was just a matter of time. One hundred twenty-six days of continuous sunshine and still not a cloud in sight. 
"Morning, George," Hugh called fondly, leaning out the car window and taking his paper.

"Can't complain, Mr. Bundy. Looks like another goddamn sunny one to me."

A beautiful person. Everybody really loved that guy. Sometimes Hugh wished that he were blind. There was no report of earthquakes in the newspaper, but that, too, was probably only a matter of time.

"Poor George," sighed Hugh as he drove off. "Out there rain or shine. Frankly, I could do without his smartass cracks."

At the garage on the corner of Broadway and 6th, Hugh tapped his boss on the back. Wismer jumped and his hands flew to his face. He was holding a clipboard at the time, a large metal clamp at the top. Hugh stared at the welt that had formed on the bridge of the dispatcher's nose and concluded that the phone call had been a hoax.

"I'm here," he disclosed tentatively. Wismer glared at him with contempt. "I've arrived," Hugh insisted.

"Arrive relaxed," snarled Wismer. "Take the Extracar. Number 50688 over there. Here's your schedule, wise guy."

But it wasn't a schedule at all. The slip of paper was crammed with a long list of weekly attendance figures at first-run movie houses throughout the entire city. The Sound of Music was packing them in. This pleased Hugh for he believed in Julie Andrews. Scrawled at the bottom in pencil was the notation HB 33. Hugh closed his zipper. As he started to leave, Wismer thoughtfully stroked his glabella and called after him, "Rubber soles, eh Bundy?"

Hugh didn't care for the tone of his voice, but they were rubber. Naturally a man who works on Saturday is fair game. He held his tongue.

Other companies had buses that were cerulean blue or green or red. Hugh's bus was mustard but clean. He wheeled it out into the public eye. The eye was brown. All morning strange people came and went. Hugh remained fixed like a capstan. It was lonely work, and dangerous too. At Wilshire, a gray-haired woman wearing white gloves got on cock-a-hoop. She whispered in his ear, "Because you resent me, you will not soon forget the things I have said." The fare box, fortunately, was sealed.

After the murder of Larivière, the drivers had clamored for bullet-proof glass shields between themselves and the passengers. The president of the company pointed out that expensive bullet-proof glass had not saved Eichmann, and sealed the boxes. "Regarding our associate, Larivière," he expanded, in an unprecedented follow-up leaflet aimed at the still-murmuring radical fringe, "we must accept the fact that his number was up."

Hugh glanced slyly at the rear-view mirror and surveyed his crowded bus. They aren't all bad, he thought, but there is a dissident element loose among them. I must watch my step.

On the corner of Santa Monica stood blind George. "No one can stay put in this lousy town for two seconds," Hugh muttered in disgust. George had just exited from a pawnshop and was smiling ambiguously the way blind people who have just exited from pawnshops do. He appeared to make some insignificant gesture with his right hand, as if adjusting the folds of a breast-pocket handkerchief, before he crumpled to the sidewalk. 
Veering to the curb, Hugh slammed on his brakes and leaped to the door. "A diet crammed with saturated fats," he announced to his astonished passengers, trying to allay their fears. "If he lives through this, he'll have to jog regularly and cut way down on his egg intake."

Hugh bent low over blind George and cocked an ear to his chest. Not a peep. The owner of the pawnshop came running out in a beige jump suit and matching huaraches.

"Is he ...?"

"I'll say," said Hugh.

"Oh my God! Look at that!"

Protruding from the exact center of George's head was a short, gailyfeathered wooden shaft. Its diminutive size plus the accuracy of the shot and depth of penetration led Hugh to the conclusion that the arrow had been fired from a medieval crossbow. He yanked the arrow but only succeeded in raising George's head several inches off the pavement.

"I guess it must be one of those barbed tips," he explained. "Poor George!"

"What do you know?" screamed the pawnshop owner. He seemed to be addressing someone just beyond the crowd that had gathered across the street.

"I think you'd better call the police," advised Hugh.

"I give everybody the same. Everybody! A fair shake. I've got overhead, do you hear? OVERHEAD! Rent, problems. For God's sake, what do you want from me?"

The man was hysterical. Hugh knew what he had to do. He would slap him once with the palm and once with the back of his hand.

"Always when you need them they're never here," complained the pawnbroker, and hurried back into his store.

It was a sign. Worse than Hugh had ever imagined. If even the blind weren't safe in LA . . . and in broad daylight, too! Hugh saw that it was only a matter of time now and took steps. He drove defensively, cannily, with exquisite care, waiting for all traffic to pass before inching out into the middle of the road and, at the very next stop, quickly returning to the curb with an audible "aaahhhhhh!"

The passengers became restless. The passengers became critical and abusive. Many stormed off the bus shouting incoherently. A tightly-knit Oriental family rose as one and, eyes downcast, departed in silence. The elderly woman with white gloves was the last to go, humming as she stepped through the door.

"Thank you, young man," she called pleasantly from the sidewalk. "Your problem is that of Father Junipero Serra. I tried to help but (hee hee!) it's all over now. Bye-bye."

Hugh inched away from the curb thinking: It's more than the weather, more than the one hundred twenty-six consecutive days. They feel it, too. The fear that is bigger than Marineland. It is the thought of the last stop that makes us all so alert. Pinpointing the cause, Hugh was comforted. Unawares, he had been lulled into a false sense of order.

Something was amiss. This bus that he believed to be empty of all passengers was not empty of all passengers. Glancing through the rear-view mirror, Hugh spotted a lone figure huddled in a corner at the back. It might be crouch- 
ing for all he knew. It might be beautifully equipped like a Green Beret. Some freaky spring-wound Jack who would jump him for kicks or small change. Hugh swerved wildly to avoid a pothole. When he looked again the back seat was empty. He released the safety catch on his .22 .

A head appeared behind the next to the last seat. Good Lord, he was only a kid! Long blond curly hair but weird white staring eyes that resembled sugar cubes. Casually taking his right hand from the wheel, Hugh loosened his belt and wriggled his revolver around. To eliminate dirty-filthy scum like that from the face of the earth was not murder. It was hygiene.

The boy stood up and stepped to the aisle. A tall one and practically naked except for his faded bell bottoms. The smutty lout. His bare, hairless chest was as smooth as a bathtub, brown as a cigarillo. There were company regulations against that sort of thing. No one had ever before ridden Hugh's bus bare back. Had he disrobed in the rear as part of some terrible ritual? His white teeth looked painted. How unnaturally still he was! Hugh could not concentrate on his driving. This, he admitted, is a life style I cannot cope with at my age. It smacks of queer cultic practices and strange rites often involving others, not to mention music and art. No shit, this time I am in over my head for sure.

It was all in the mirror but late like something you read about afterward in the papers. The kid now standing right behind him, no more than six inches away. His body giving off the dark, copsy smell of wild rice. Around his neck a small silver chain. There was nothing on the chain. No iron cross, no Scorpio, no peace. NOTHING! Hugh's mind boggled and grabbed for the gun. Hugh's fingers drooped like an empty glove. Damnit, he thought, Larivière was a patsy, but I am native born. Can such a melancholy thing happen to a take-charge guy?

Uh oh. The kid removed a long, tapered object from his back pocket and bent forward. What's this? A gaudy mother-of-pearl switchblade cuchillo favored by Mexican-Americans from Alvarado Street for cutting gringo cantaloupes. What's this? The deadly Japanese short sword with hilt wrapped in ceremonial cloth bearing black calligraphic promise of honorable disembowlment. What's this? Looking into the mirror, the kid combed his hair and made a neat part. Then he raised his aerosol can of wave set, pressed the button, and fired a fine mist over his head.

"God help me!" gagged Hugh, throwing open the door. "It's gas!"

The slow-moving bus jumped the curb, stopped at a telephone pole. Clutching at his collar, Hugh crawled outside and fell to the pavement.

The startled kid looked down at him. Seeing the color of Hugh's face, he gave a long, low whistle.

"Wow! Just like Dustin Hoffman on the Greyhound in Midnight Cowboy," he noted approvingly, and fled. His long hair streaming behind him like a golden windsock, he sped away into the white hot afternoon until his body dissolved in the glare.

Mrs. Bundy (Hugh's wife in the kitchen) cried. The rich heady sauce of her days had boiled off leaving a scorched bottom. There would never be another Bundy, Hugh. She thought it wisest to leave the phone in his name.

Mrs. Bundy (Hugh's mother in the nursing home) cried. She dimly re- 
membered that, yes, she once did have a son whose name was Horace or Henry or Harold. Those were the only choices available at the time. Today young people are so different, she said. They don't seem to be afraid of anything: the whole alphabet, nightfall.

\section{Sense of Injury}

\section{Jeremy Shaw}

Yesterday I killed a tree. Just a little one, to be sure-I didn't think I could kill a big one. I pulled it up by its roots and cut it up with an axe into small pieces which I then dropped down the sewer. I watched it go down. I know, too, a little about the light haired girl who lives a mile down the road. Her name is Jennifer.

As the leaves change, every year, I see her in the distance on her mare. But I almost never get close to her.

My father says I am blocking the sewer with all that wood.

I go fishing, sometimes. The other day I was fishing, killing even the smallest ones-then throwing them back to watch them come to life again-down near the place where the stream falls, where Jennifer sometimes waters her mare. She was swimming, this time. She was alone.

She has long hair and it was wet. Then I hooked a big trout and when I looked again she was gone. So I went down there myself and swam, afterwards, leaving my clothes where she had left hers. I hope she was watching, but I don't know that she was. Wouldn't it be something if she did see me? I'll go there again. I hope she will, too.

Today I was allowed to slaughter a hog. My father says I'll have to learn how to do it all, eventually, and so I might as well start now. There was a lot of blood and a lot of screaming. If anything has real pain when it's dying, it's a hog. 